\title{
ARCHEOLOGISCH ONDERZOEK IN DE SINT-SALVATORSKATHEDRAAL TE BRUGGE (1992-1994)
}

\author{
DIRK VAN EENHOOGE ${ }^{\circ}$
}

Toen bij de aanvang van de restauratie van de toren van de kathedraal $^{1}$ in 1992 duidelijk werd dat omvangrijke en ingrijpende graafwerken in de toren zouden gebeuren, besloot de Afdeling Archeologie van het Bestuur Monumenten en Landschappen van de Vlaamse Gemeenschap, na een voorstel van dr. L. Devliegher, deze werken van nabij te volgen. Het onderzoek gebeurde overigens in nauwe samenwerking met dr. L. Devliegher, en bestond hoofdzakelijk uit de opmeting en analyse van een doorsnede doorheen de meer dan 3 meter diepe opeenstapeling van archeologische lagen, de registratie van diverse vondsten tijdens de graafwerken en de interpretatie van de talrijke proefboringen die ten behoeve van het stabiliteitsonderzoek in de muren werden uitgevoerd.

Wat volgt is een eerste voorstelling van de onderzoeksresultaten, en van een aantal interpretaties en hypothesen die tijdens het verdere verloop van restauratie en onderzoek op hun waarde zullen worden getoetst.

Voorlopig is het mogelijk de waarschijnlijk meer dan 1100 jaar lange bouwgeschiedenis in 5 grote bouwperioden te verdelen.

\section{Periode 1 (9de ?-10de eeuw)}

Tot de oudste bouwactiviteit op deze plaats behoren 2 parallel lopende muren, opgebouwd in glauconiethoudende zandsteen, beter bekend als veldsteen (plans, nrs. 40 en 47). De oostelijke muur (nr.

- Archeoloog bij het Bestuur Monumenten en Landschappen van het Ministerie van de Vlaamse Gemeenschap. Oude Dorpsweg 81, Varsenare.

1. Voor een meer algemene bespreking van de restauratie van de toren, zie In de steigers. Monumentennieuws uit West-Vlaanderen, jg. 1 (1994), $\mathrm{nr} .1$. 
40 ) is bewaard tot op niveau $-1,80 \mathrm{~m}^{2}$ en is op niveau $-2,60 \mathrm{~m}$ gefundeerd op een laag geel zand waarin kleine lenzen lichtrood zand (nr. 49), waarboven zich een tweede, dunnere laag bevindt (nr. 53), die is samengesteld uit afwisselend donkere en lichte zandlaagjes. Beide lagen hellen sterk af in westelijke richting en behoren waarschijnlijk tot de zuidelijke flank van de "hoge" duinrug die in de Brugse binnenstad van de omgeving van de Smedenpoort over het Zand tot voorbij de Markt loopt ${ }^{3}$. Of dat ook het geval is voor de twee hierop aansluitende, horizontale lagen is minder duidelijk. De onderste laag (nr. 52) bestaat uit lichtgeel zand, de bovenste ( $\mathrm{nr}$. 51) waarop de westelijke veldstenen muur (nr. 47) is gebouwd, bestaat uit donkerkleurig zand. Wellicht zijn beide lagen te beschouwen als nivelleringslagen die op het sterk hellende terrein werden aangebracht om de bouw van deze muur mogelijk te maken.

Een eerste opvullingslaag binnen het gebouw (nr. 50) bestaat uit vermengd zand, evenals een tweede, massieve opvulling (nr. 42) die van de onderliggende lagen is gescheiden door een dun laagje kalkmortel. Dit alles betekent dat beide veldstenen muren stratigrafisch goed met elkaar zijn verbonden : bijgevolg kunnen we uitsluiten dat de westelijke muur, die we enkel in de doorsnede $\mathrm{AB}$ konden bestuderen ${ }^{4}$, in feite tot een latere bouwfaze behoort.

Helaas is het niet mogelijk om op basis van de beschikbare gegevens een idee te vormen van de constructie waartoe deze muren behoren. Opvallend is wel de geringe diepte van de funderingen $(0,70 \mathrm{~m})$ en de eveneens geringe breedte (binnenwerks $3,60 \mathrm{~m}$ ) van het gebouw. Over de breedte van de muren zelf bestaat eveneens geen duidelijkheid. De westelijke muur zit verborgen onder latere constructies, de oostelijke muur die nu onderaan $1,75 \mathrm{~m}$ breed is, werd waarschijnlijk gedeeltelijk uitgebroken bij de aanleg van latere funderingen. Op basis van een verstek in de fundering van de oostelijke muur, en een hiermee samenvallende latere puinlaag kunnen we daarentegen wel het vloerniveau binnen het gebouw vastleggen op niveau $-1,92 \mathrm{~m}$. De

2. Alle niveau's zijn gemeten vanaf het chronologisch jongste vloerpeil in de toren, dat ook na de restauratie het nieuwe vloerpeil wordt.

3. Tentoonstellingsbrochure Dieper inzicht in de Brugse ondergrond, Brugge, 1993 , p. 5 en fig. 6.

4. De houding van stabiliteitsingenieurs is terzake meermaals tegenstrijdig met die van archeologen. 


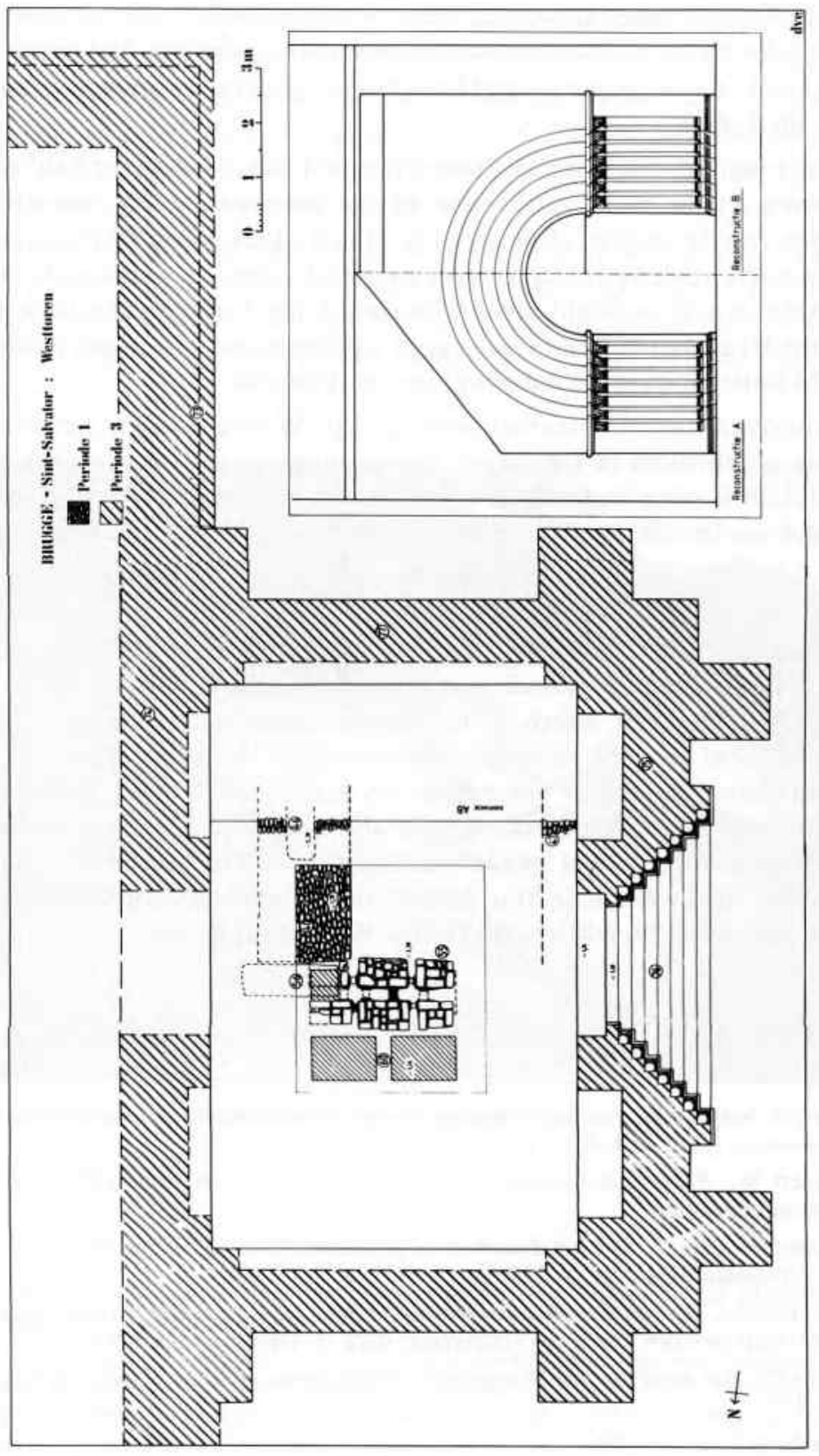

हิ 
oostelijke muur bleef bewaard over een lengte van $2,50 \mathrm{~m}$, van de noordelijke en zuidelijke muren verdween elk spoor door latere verbouwingen, de aanleg van grafkelders, en andere, recentere ingrepen in de bodem.

Zelfs als we, zonder daar in feite één enkel bewijs voor te hebben, aannemen dat de twee veldstenen muren behoren tot het westelijk gedeelte van de oudste of één van de oudste kerken op deze plaats, blijven verscheidene interpretaties mogelijk. Een verantwoorde interpretatie wordt wellicht slechts mogelijk als verder onderzoek in de kathedraal aansluitende gegevens oplevert, en als meer duidelijkheid ontstaat over de datering van het gebouw.

Ook hierover staat momenteel weinig vast. Waarschijnlijk werd het gebouw afgebroken in het begin van de 11 de eeuw ${ }^{5}$, maar over de bouwdatum is niets bekend, ook niet als we de, niet-bewezen, hypothese aanvaarden dat de muren behoren tot een oudere Sint-Salvatorskerk.

Over de oudste geschiedenis van de kerk is namelijk zeer weinig bekend. De eerste vernoeming dateert uit 988 , in een bul van paus Johannes $\mathrm{XV}^{6}$. In 1086 wordt de kerk voor het eerst als parochiekerk vermeld, in een oorkonde van bisschop Radbodus II van NoyonDoornik ${ }^{7}$. Algemeen wordt echter aangenomen dat de kerk in de 9 de eeuw werd gesticht, meer bepaald rond $850^{8}$. Verondersteld wordt dat Sint-Salvator van in het begin een stadskerk was en ontstond vóór de Onze-Lieve-Vrouwekerk ${ }^{9}$. De stichting van deze kerk wordt, op overigens niet geheel onaanvechtbare gronden, gesitueerd rond $870^{10}$. Vast staat wel dat de Sint-Salvatorskerk ontstond door afsplitsing van de parochie Sint-Michiels/fiscus Weinebrugge die zich in de

5. Voor een bespreking van deze datering en de gebeurtenissen die ermee samengaan, zie verder in dit artikel.

6. Ryckaert M., Brugge. Historische stedenatlas van België. Brussel, 1991. p. 50, zonder bronvermelding.

7. Ryckaert M.. o.c., p. 50 : het document is gepubliceerd in Gysseling M. en Koch A.C.F., Diplomata Belgica, I, p. 295.

8. Devliegher L., De Sint-Salvatorskathedraal te Brugge. Geschiedenis en Architectuur (Kunstpatrimonium van West-Vlaanderen, deel 7), Tielt/Bussum, 1981, p. 15.

9. Strubbe E.I.. De parochies van Brugge vóór de XIle eeuw, in Album English, Brugge, 1952, p. 377.

10. Strubbe E.I., o.c., p. 376. 
8ste of vroege 9de eeuw als nieuw domaniaal centrum in het noorden van het domein Snellegem had ontwikkeld ".

Als nu de Sint-Salvatorskerk inderdaad als stadskerk is gesticht, is de kans groot dat de veldstenen muren die we binnen de toren aantroffen inderdaad tot de oudste kerk op deze plaats behoren, en dus omstreeks 850 kunnen worden gedateerd.

Volgens een andere visie echter werd de kerk opgericht als hulpkerkje voor enkele ver buiten het domaniaal centrum wonende landbouwers van Weinebrugge-Sint-Michiels ${ }^{12}$. In dit geval was de oudste constructie waarschijnlijk een houten kerkje, dat pas later door een

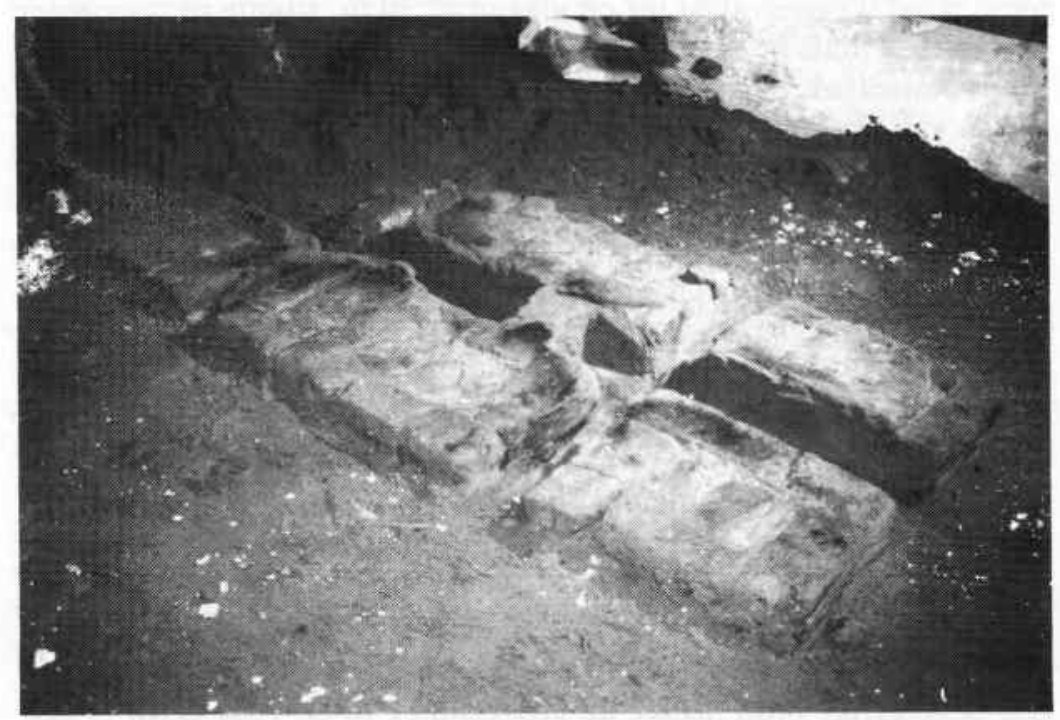

Afb 2 : Tufstenen sokkel van gietput voor klokken.

11. Ryckaert M.. Topografische studie van de stad Brugge in de Middeleeuwen (licentiaatsverhandeling), Gent, 1971. p. 94.

12. Noterdaeme J.. Studiën over de vroegste kerkgeschiedenis van Brugge : II. De fiscus Weinebrugge, in Sacris Erudiri. 7 (1955), p. 135. Dhondt J.. De vroege topografie van Brugge. in Handelingen der Maatschappij voor Geschiedenis en Oudheidkunde te Gent, nieuwe reeks, deel 11 (1957). p. 19-21. 
veldstenen kerk werd vervangen, en moeten we dus de eerste veldstenen constructie in datering laten opschuiven in de richting van de 10de eeuw.

Hoe dan ook zijn beide opvattingen over het ontstaan van de SintSalvatorskerk nauw verbonden met verschillende visies omtrent het ontstaan van Brugge, en de rol die allerhande vroegere kleine nederzettingen hierin hebben gespeeld.

\section{Periode 2 (11de-eind 12de eeuw)}

Toen voor het gieten van een zware funderingsplaat de grond in de toren werd weggegraven tot op niveau $-2,50 \mathrm{~m}$, stootte de aannemer op enkele "muurtjes" in tufsteen. Uit het daaropvolgend archeologisch onderzoek bleek dat we te maken hadden met sporen van het gieten van klokken in de toren zelf.

Vooraleer deze resten te beschrijven is het wellicht nuttig in het kort de klokkengieterskunst te beschrijven in de periode 9de-12de eeuw. Reeds in het Karolingische rijk waren kerkklokken een algemeen voorkomend verschijnsel, zoals ondermeer blijkt uit de capitularia (verordeningen) van de Karolingers ${ }^{13}$. Als klokkengieters waren blijkbaar vooral monniken bedrijvig, en de meeste klokken werden in de kloosters zelf gegoten, ook als ze voor andere kerken waren bestemd. Toch moeten in of nabij de kerken zelf reeds klokken zijn gegoten, want er is een incident bekend waarbij door de onvoorzichtigheid van de klokkengieters in Salzburg in de 12de eeuw een kerk afbrandde ${ }^{14}$. Het ter plaatse gieten van klokken werd pas later frekwenter toegepast, toen de klokkengieterskunst "geseculariseerd" was, en er ook beduidend grotere klokken werden gegoten.

Een belangrijke bron inzake de giettechniek in de 12 de eeuw is een verhandeling van Theophilus, een monnik uit het Benediktijnerklooster van Helmarshausen, die waarschijnlijk omstreeks 1125 de verhandeling De diversis artibus schreef, waarin uit het hoofdstuk over het klokkengieten niet alleen zijn theoretische maar ook praktische kennis blijkt ${ }^{15}$.

13. Lehr A., Van paardebel tot luiklok, Zaltbommel, 1981, p. 41.

14. Lehr A., o.c., p. 44, zonder bronvermelding.

15. Over Theophilus en zijn giettechniek, zie Lehr A., o.c., p. 47-53. 
De eerste stap was het maken van de gietvorm, vervaardigd op een horizontale houten vormspil, en die, volledig afgewerkt, bestond uit : een uitgeholde lemen kern, daarrond de "valse" klok vervaardigd in was zoals ook de kroon, de gietloop en de ontluchtingskanalen bovenaan, dit alles opnieuw ingekapseld in een lemen mantel. Eens de gietvorm volledig droog was, werd een gietput gegraven, die in eerste instantie diende voor het bakken van de gietvorm. Op de bodem werd in vuurvaste stenen een sokkel gemetseld, waarop vervolgens de gietvorm werd geplaatst. $\mathrm{Na}$ het aanbrengen van enkele openingen onderaan de vorm, werd in de stenen sokkel een vuurtje gestookt dat de was van de "valse" klok deed smelten. Hierna werden de gaten opnieuw gedicht en de volledige vorm gebakken in een heviger vuur. $\mathrm{Na}$ het uitharden van de nu holle gietvorm werd de gietput gevuld met aarde die zorgvuldig werd aangestampt, waarna het gieten van de klok kon plaatshebben. Het brons hiervoor liep via een kanaal uit een nabij de gietput geplaatste schachtoven in de vorm.

Wat we nu in de toren van de Sint-Salvatorskerk aantroffen zijn de resten van twee opeenvolgende gietputten met hun sokkels. De onderste sokkel (plans, nr. 60) bestaat uit vier "eilanden", elk 1,80 m op $0,80 \mathrm{~m}$ groot, en gescheiden door twee elkaar kruisende kanalen, 24 à $40 \mathrm{~cm}$ breed. De volledige sokkel meet aldus $2,64 \mathrm{~m}$ op $2 \mathrm{~m}$, is opgebouwd uit drie lagen in leem gezette tufsteen, en is $26 \mathrm{~cm}$ hoog; het oppervlak van de sokkel bevindt zich op niveau $-3,26 \mathrm{~m}$. Bij de kruising van de kanalen overspannen brugjes in leem deze kanalen, die zelf, evenals de buitenzijden van de sokkel, volledig met leem zijn bezet. In de kanalen zelf is de leem duidelijk verbrand, de buitenzijden van de sokkel daarentegen niet. De ingangen van de kanalen hellen lichtjes omlaag.

$\mathrm{Na}$ het gieten van de eerste klok werden de kanalen zorgvuldig opgevuld met fijn wit zand, waarna het niveau in de gietput werd verhoogd. Achtereenvolgens werden aangebracht : een $16 \mathrm{~cm}$ dikke laag gemengd zand ( $\mathrm{nr} .59$ ), een opnieuw $16 \mathrm{~cm}$ dikke puinlaag ( $\mathrm{nr}$. 58) waarin veel brokstukken verbrande leem met duidelijke sporen van groen geoxideerde metaalresten (fragmenten van de kern of mantel van de eerste gietvorm), en tenslotte een $24 \mathrm{~cm}$ dikke opvulling van gemengd zand (nr. 57).

Hierop werd de tweede sokkel (nr. 55) gebouwd, nu bestaande uit zes "eilanden" van verschillende afmetingen, van elkaar gescheiden door één kanaal in de lengte, en twee dwarskanalen. De sokkel meet 
Archeologisch onderzoek in de Sint-Salvatorskathedraal te Brugge
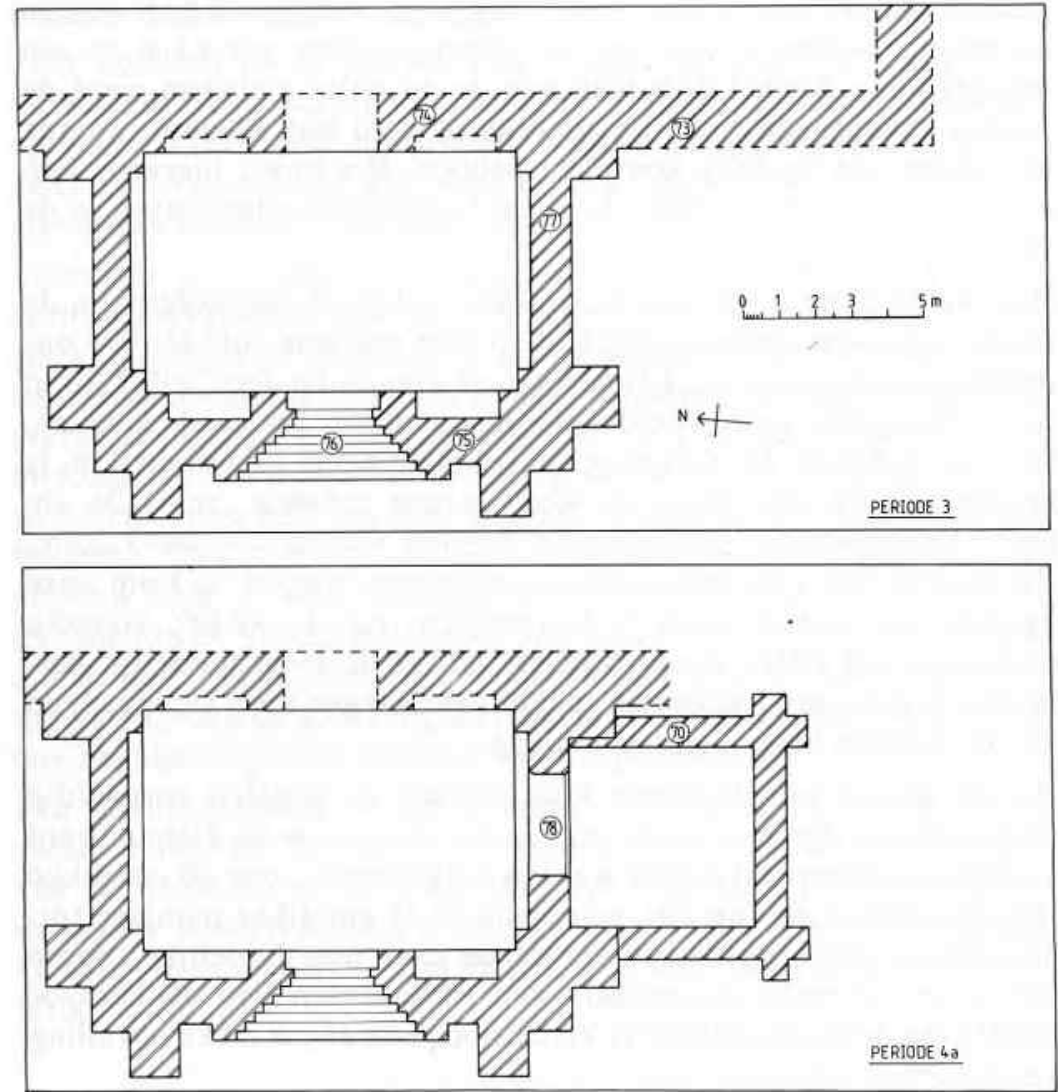

Afb. 3 : Bouwgeschiedenis van de toren en de Sint-Jacobskapel, periodes 3 tot 5 (eigen tekening). 
D. Van Eenhooge
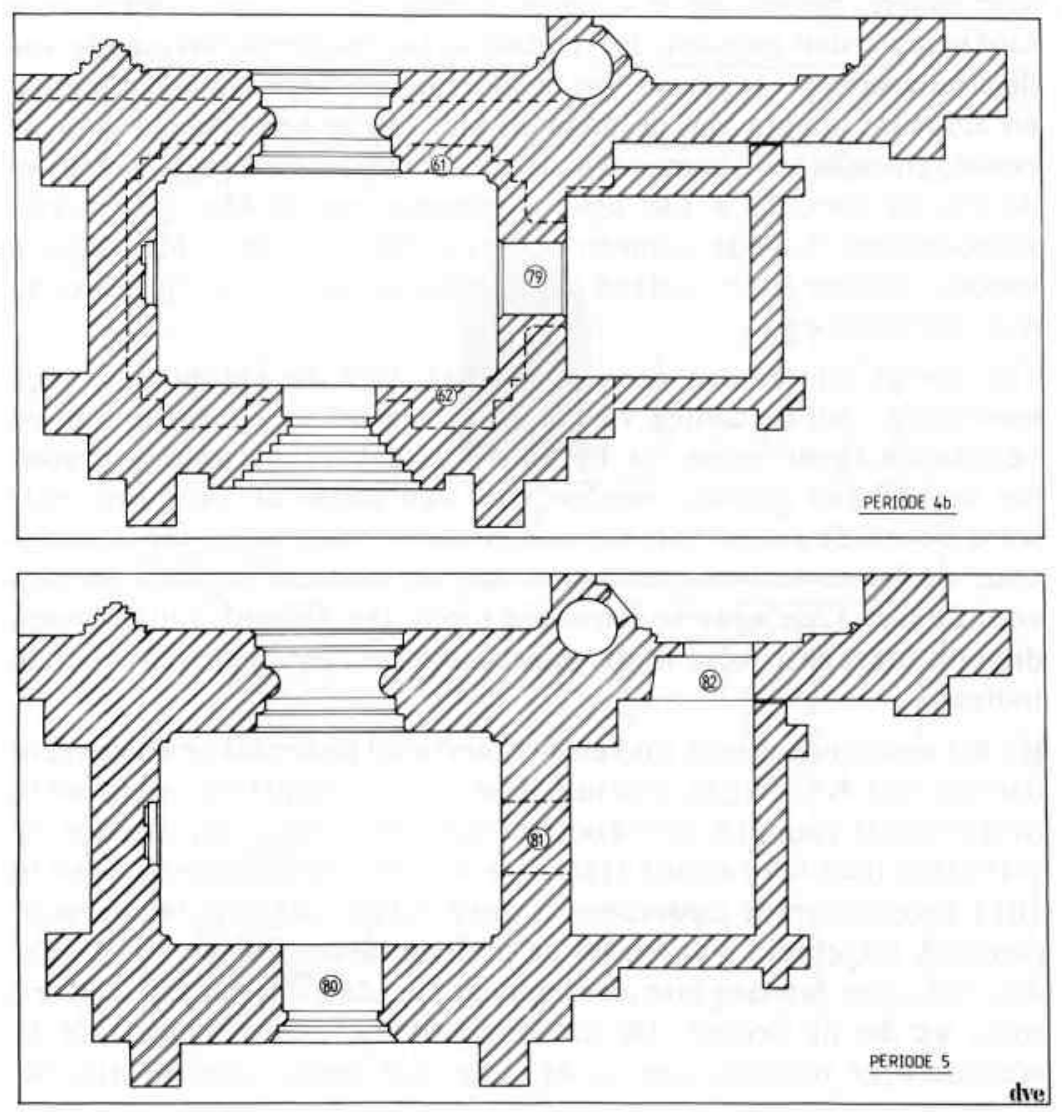
$2,64 \mathrm{~m}$ op $1,30 \mathrm{~m}$, is opgebouwd uit twee lagen in leem gezette tufsteen, en is $20 \mathrm{~cm}$ hoog ; opnieuw zijn alle wanden met leem bezet en zien we brandsporen enkel in de kanalen, niet aan de buitenzijde van de sokkel. Ook bovenop de sokkel zien we nu brandsporen ${ }^{16}$, die niet alleen aanduiden dat de sokkel volledig bewaard bleef, maar ook een uitleg verschaffen voor de ook hier aanwezige lemen brugjes rond de kruispunten van de kanalen : uit het patroon van de brandsporen kan afgeleid worden dat elk kruispunt afgedekt was met een vierkante plaat. Uit de aanwezigheid van twee zulke kruispunten, en het feit dat de centrale eilanden beduidend groter zijn dan de vier andere, menen we te kunnen afleiden dat op deze sokkel twee klokken werden gegoten. Bovendien is het mogelijk, uitgaande van de stratigrafische gegevens, bij benadering de diepte van elke gietput en aldus de hoogte van de gegoten klokken te berekenen : voor de eerste, grootste klok komen we uit op een maximale hoogte (inclusief de kroon) van 120 à $130 \mathrm{~cm}$; uitgaande van de klassieke vormverhoudingen moet de diameter onderaan ongeveer hetzelfde gemeten hebben. De twee latere klokken moeten aanzienlijk kleiner zijn geweest : $\max .60 \mathrm{~cm}$ hoog.

Tot dusver zijn er dus geen problemen. Ook de chronologie leek eenvoudig : bij de aanleg van de gietput werd een gedeelte van de veldstenen funderingen uit Periode 1 uitgebroken, zodat vaststaat dat de klokken gegoten werden voor een toren die gebouwd was/ werd boven de resten van de vroegere constructie. Het lag dan ook voor de hand, te veronderstellen dat de klokken gegoten werden voor de laat-12de-eeuwse romaanse toren. Het gebruik van tufsteen, die ook toegepast werd in de romaanse toren, leek een aanvullende indicatie.

$\mathrm{Bij}$ het onderzoek van de sokkels was verbrand materiaal gerecupereerd dat aan het Koninklijk Instituut voor het Kunstpatrimonium werd overgemaakt voor een radiokoolstof-datering. Groot was dan ook de verbazing toen het rapport klaar was en het staal gedateerd werd in 1017 (gecalibreerde ouderdom) ; deze eerder fictieve datum moet eigenlijk uitgebreid worden tot de periode tussen 980 en 1040 . Hoe dan ook een datering die veel vroeger is dan de romaanse toren zoals we die nu kennen. De datering zelf lijkt betrouwbaar (zie de afzonderlijke bijdrage van ir. M. Van Strydonck). Het houtskool-

16. De oudste sokkel kon slechts zeer summier worden onderzocht. 


\section{Van Eenhooge}
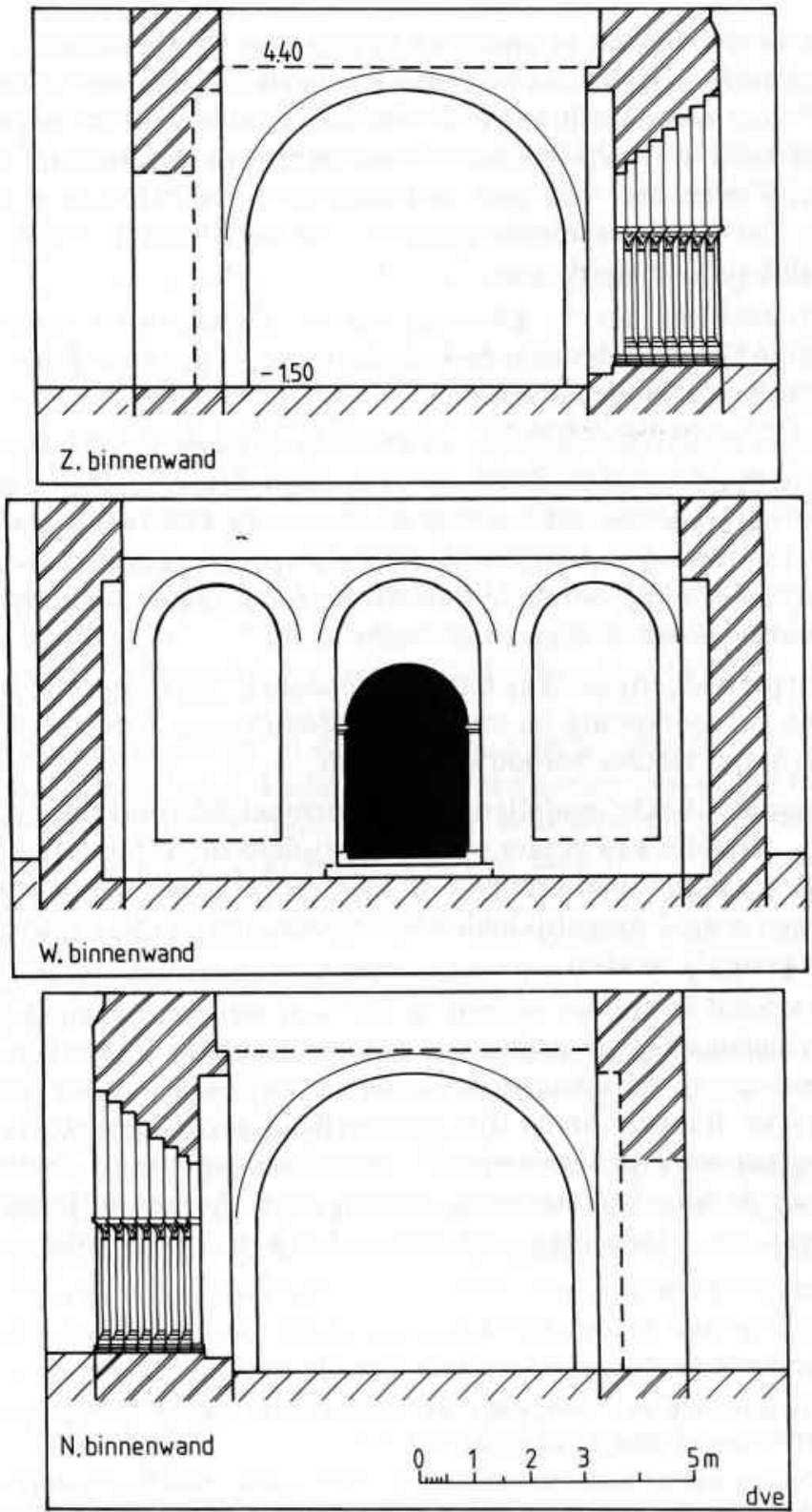

Afb. 4 : Reconstructie van de binnenwanden van de romaanse toren, benedenverdieping (eigen tekening). 
poeder in de sokkels is enkel afkomstig van de gietvorm, waarbij waarschijnlijk enkel klein hout werd gebruikt, zodat een "oud-houteffect" zeer onwaarschijnlijk is ; en zelfs indien dit de ouderdom van het staal zou beïnvloeden, is het heel onwaarschijnlijk dat de afwijking meer dan 100 jaar zou bedragen. De datering sluit wel aan bij het reeds vermelde gegeven dat de Sint-Salvatorskerk al vóór 1086 parochiekerk was.

Dit betekent dus dat we afweten van het gieten van klokken omstreeks 1017 voor een niet-bestaande toren, tenzij we één van de volgende hypothesen aanvaarden.

Een eerste mogelijkheid is dat de klokken gegoten werden voor een toren die in de eerste helft van de 11 de eeuw een vroegere constructie verving, maar die zelf op het einde van de 12 de eeuw door een nieuwe toren werd vervangen, waarbij elk spoor van de $11 \mathrm{de}$-eeuwse toren verdween, bijvoorbeeld doordat de funderingen volledig geïncorporeerd werden in die van de latere toren ${ }^{17}$.

Een tweede mogelijkheid is dat de "romaanse" toren in feite vroegromaans van oorsprong is, en dat de 12 de-eeuwse elementen (portaal, vensters) slechts verbouwingen zijn.

Aan geen van beide modellen kan momenteel de voorkeur gegeven worden ; wellicht kan verder onderzoek tijdens de restauratie nieuwe elementen aan het licht brengen. In ieder geval genereert het tweede model een aantal mogelijkheden die tijdens het verdere onderzoek kunnen getoetst worden.

In dit verband willen we wijzen op het toch wel merkwaardig uitgesproken rechthoekige grondplan van de toren dat eerder lijkt te verwijzen naar een vroege Maaslandse westbouw ; weliswaar ontbreken hier de typische flankeertorens die natuurlijk in een 12 de-eeuwse verbouwing kunnen zijn verdwenen ${ }^{18}$. Anderzijds behoort de (romaanse) toren van de Sint-Salvatorskerk tot een groep kerken in (vooral de kuststreek in) Vlaanderen, die sterk afwijken van de Maaslandse

17. Het is natuurlijk niet onmogelijk dat overblijfselen alsnog verdwenen tijdens latere verbouwingen, aanleg van grafkelders, e.d.

18. Ten zuiden van de toren bevindt zich de 14de-eeuwse Sint-Jacobskapel waarin onderzoek vlakbij de toren onmogelijk was door reeds gegoten betonfunderingen en drie grafkelders; ten noorden van de toren is vóór het voltooien van de restauratie onderzoek onmogelijk. 
types ondanks de aanwezigheid van een westelijke voorbouw of zelfs een westtoren, "maar deze hebben veel meer het karakter van een voorgevel waarvan het hoofdmotief de monumentale, in de aslijn van de kerk gelegen ingangspoort is" ${ }^{19}$. Deze kerken verschillen hierin van de meeste kerken in Vlaanderen, waar een vieringtoren gebruikelijk is en sluiten eerder aan bij een groep Franse kerken.

Ter afronding vermelden we nog twee feiten die wellicht ook hun steentje kunnen bijdragen in de oplossing van dit probleem : (a) in 1127 werd de kerk door een brand geteisterd ${ }^{20}$ en (b) tijdens de restauratiewerken werden in een steunbeer een zuilbasis en kapiteeltje in veldsteen aangetroffen, die, getuige hun zeer eenvoudige vormgeving, van een vroeger gebouw afkomstig moeten zijn.

Samenvattend kunnen we van de geregistreerde gegevens enkel de volgende met zekerheid in Periode 2 situeren :

- de reeds besproken sokkels van klokkengietersputten;

- een puinlaag (plans, nr. 39) bestaande uit kalkmortel en brokken veldsteen, afkomstig van de afbraak van de constructie uit Periode 1 ;

- een put, uitgegraven in deze puinlaag én de vroegere muur, met onderaan een laagje kalkmortel op een aarden opvulling (nr. 46), hierboven een gemengde laag met veldsteen en beenderen (nr. 48 ) ; de put was afgesloten met een laag mortel en veldsteenbrokjes (nr. 41) ; waarschijnlijk gaat het hier niet om een graf (dat NW zou georiënteerd zijn !) maar om een herbegraving van beendermateriaal dat tijdens de werken aan de nieuwe toren werd opgegraven;

- een paalgat (nr. 44) dat ofwel verband kan houden met de constructie van de schachtoven voor het bronsgieten, ofwel met een houten stelling voor de nieuwbouw;

- een dun laagje donkere aarde (nr. 38), wellicht overblijfsel van de nivelleringslaag waarop de vloer in de 11 de eeuw rustte.

Hierboven bevindt zich opnieuw een puinlaag (nr. 30) met kalkmortel en brokken veldsteen, afkomstig van de afbraak/verbouwing van de vroeg-romaanse toren, waardoor we ons in feite reeds bevinden in de gebeurtenissen die we situeren in de volgende periode.

19. Lemaire R., De romaanse bouwkunst in de Nederlanden, Leuven, 1954, p. 209.

20. Devliegher L., o.c., p. 15. 


\section{Periode 3 (einde 12de eeuw-1358)}

Gezien de moeilijkheden hierboven vastgesteld, zullen we bij de beschrijving van de romaanse toren deze voorlopig als een homogeen geheel behandelen. Bovendien beperken we ons tot de benedenverdieping daar enkel voor deze het onderzoek volledig is afgerond. Aangezien de toren reeds elders volledig werd beschreven ${ }^{21}$, presenteren we hier enkel de nieuwe gegevens.

De toren meet binnenwerks $10,30 \mathrm{~m}$ op $6,70 \mathrm{~m}$, afmetingen die nu schuilgaan achter een 14 de-eeuwse bakstenen parement. De hoogte van de gelijkvloerse verdieping kan gereconstrueerd worden op $5,90 \mathrm{~m}$. Details over de afwerking van de binnenwanden kwamen aan het licht door proefboringen die door de aannemer voor het stabiliteitsonderzoek werden uitgevoerd. Hieruit bleek dat de binnenwanden van spaar- en blindnissen waren voorzien. In de noord- en zuidwand bevinden zich $5,75 \mathrm{~m}$ brede en $5,45 \mathrm{~m}$ hoge rondboognissen, in de noordmuur $48 \mathrm{~cm}$, in de zuidmuur $38 \mathrm{~cm}$ diep.

De westelijke binnenwand vertoont een meer doorgedreven geleding met drie kleinere rondboognissen. Aan weerszijden van de centrale nis bevindt zich een $2,30 \mathrm{~m}$ brede, $5,40 \mathrm{~m}$ hoge en $80 \mathrm{~cm}$ diepe rondboognis, die mogelijk onderaan eindigde in een $70 \mathrm{~cm}$ hoge muurbank. De centrale nis is even hoog, maar iets breder $(2,60 \mathrm{~m})$ en slechts $50 \mathrm{~cm}$ diep. Alle nissen zijn uitgevoerd in tufsteen, het overige metselwerk is in veldsteen.

De centrale nis in de westmuur omvat de toegangsdeur die in een monumentaal portaal is gevat. Van dit portaal (nr. 76) werden bij graafwerken de basissen "in situ", een fragment van een kapiteel en kapiteelafdekplaten in een opvulling teruggevonden. Het $1,75 \mathrm{~m}$ diepe portaal telde aan weerszijden zeven flankeerzuiltjes tegen rechtstanden, uitgevoerd in Doornikse kalksteen. Op de dekplaten rustten oorspronkelijk acht rechthoekig afgewerkt rondbogen. De basissen zijn voorzien van hoekklauwen in een sierlijke bladvorm, de kapitelen laten zich op basis van de teruggevonden fragmenten reconstrueren als haakkapitelen. Het portaal springt ongeveer $45 \mathrm{~cm}$ buiten de torenmuur, wat in de tentoonstelling "Toren in steigers", gewijd aan de restauratie van de toren (3-25 september 1994 in het Provinciaal Hof te Brugge), werd gezien als een bewijs dat het

21. Devliegher L., o.c., p. 65-72. 


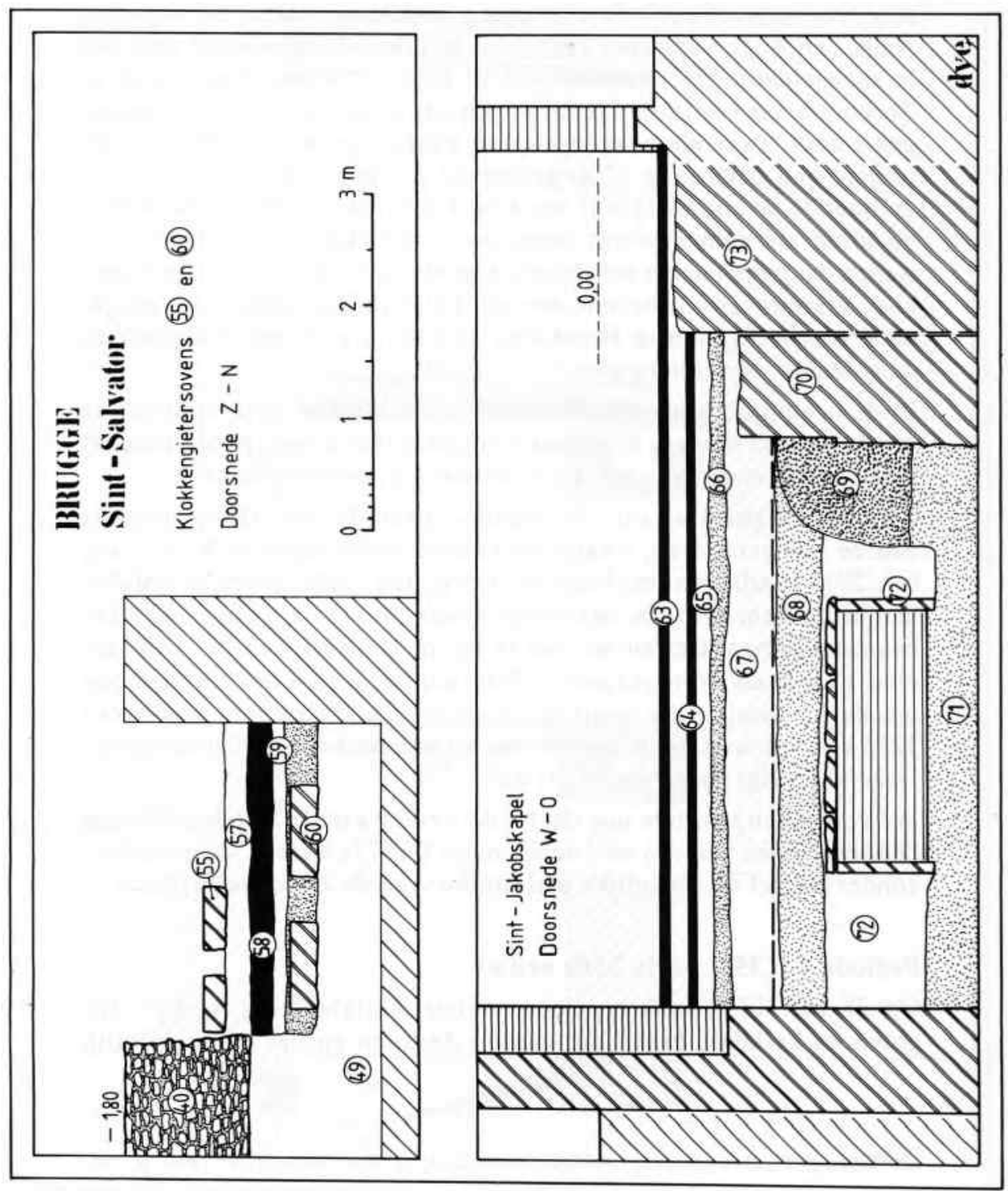

Afb. 5 : Stratigrafie van de klokkengietersovens, en in de Sint-Jakobskapel (eigen tekening). 
portaal "... dus moet voorzien geweest zijn van een dakje" (zie plan, reconstructie A). Er zijn echter andere afwerkingen mogelijk, zoals een hoger opgaand rechthoekig massief, afgewerkt met een lessenaarsdakje (reconstructie B), of zoals in de Sint-Pieterskerk te Torhout waar het (veel kleinere) portaal in de hoogte werd verdergezet door "twee kleine contreforten waartussen een blindnis" 22 . Het portaal kan omstreeks 1200 gedateerd worden. Een uitvoerige vergelijkende en stijlanalyse is meer op zijn plaats in een studie waarin de toren als geheel wordt besproken; wel kunnen we hier reeds stellen dat portalen met een dergelijk groot aantal zuiltjes vrij zeldzaam zijn. Voor zover ons bekend bevindt het dichtsbij gelegen vergelijkbaar voorbeeld zich in Broekburg (Bourbourg, Frans-Vlaanderen), met slechts vier zuilenparen ${ }^{23}$.

In de oostelijke binnenwand van de toren werden geen sporen van blindnissen gevonden. Blijkbaar werd deze wand ingrijpend verminkt bij het aanbrengen van het 14de-eeuwse bakstenen parement.

Bovenop de puinlaag (nr. 30) afkomstig van de afbraak/verbouwing van de vroegere toren, kwam een tweede, meer vermengde puinlaag (nr. 29), waarboven tenslotte een bakstenen vloer, gezet in een dun laagje zand (nr. 28). De bakstenen meten $30 \times 14 \times 6 \mathrm{~cm}$; hetzelfde baksteenformaat treffen we aan in het metselwerk van het koor dat eind 13de eeuw voltooid was ${ }^{24}$. Waarschijnlijk gaat het hier dan ook om de bevloering die werd aangebracht nadat de toren omstreeks 1275 was voltooid, en de werken aan het nieuwe koor werden aangevat. Deze vloer ligt op niveau $-1,50 \mathrm{~m}$.

We vermelden tenslotte nog dat bij de werken aan de Sint-Jacobskapel de funderingen van een veldstenen muur ( $\mathrm{nr}$. 73) werden aangetroffen, zonder twijfel de westelijke afsluitmuur van de zuidelijke zijbeuk.

\section{Periode 4 (1358- begin 15de eeuw)}

Op 28 mei 1358 brak er, door onvoorzichtigheid bij werken aan goten en kerkdak, brand uit waarbij de toren en het waarschijnlijk

22. Desmidt F., De romaanse kerkelijke bouwkunst in West-Vlaanderen, 1940, p. 108.

23. Devliegher L., Overzicht van de romaanse kerkelijke bouwkunst in Diets FransVlaanderen, in Belgisch tijdschrift voor Oudheidkunde en Kunstgeschiedenis, 22 (1953) p. 207.

24. Devliegher L.. o.c., 1981, p. 62. 


\section{Van Eenhooge}
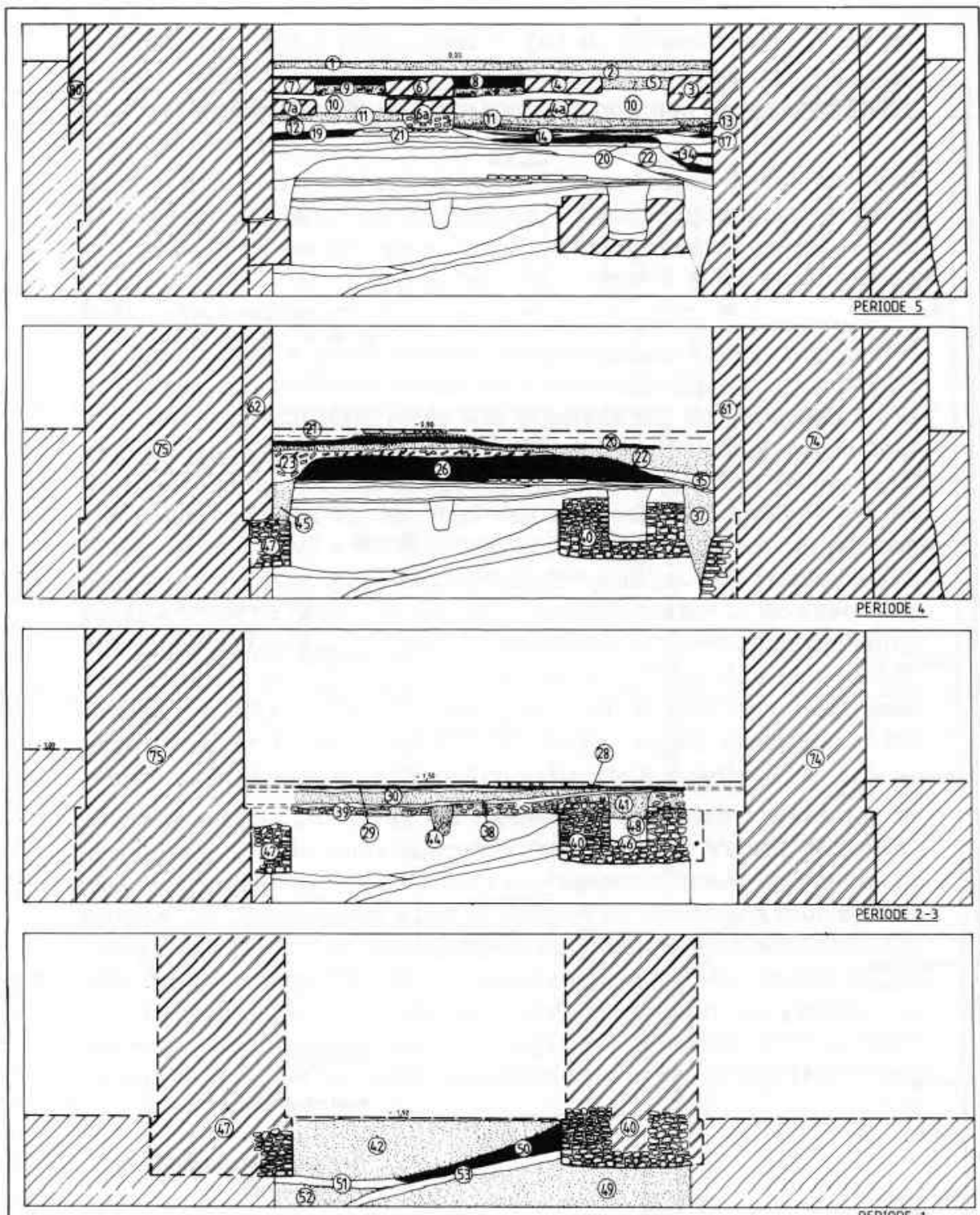

Doorsnede AB : chronoloyisehe analyse

0.m 1, 2, 3m dve

Afb. 6-7: Per bouwperiode opgedeelde stratigrafie in de toren (eigen tekening). 


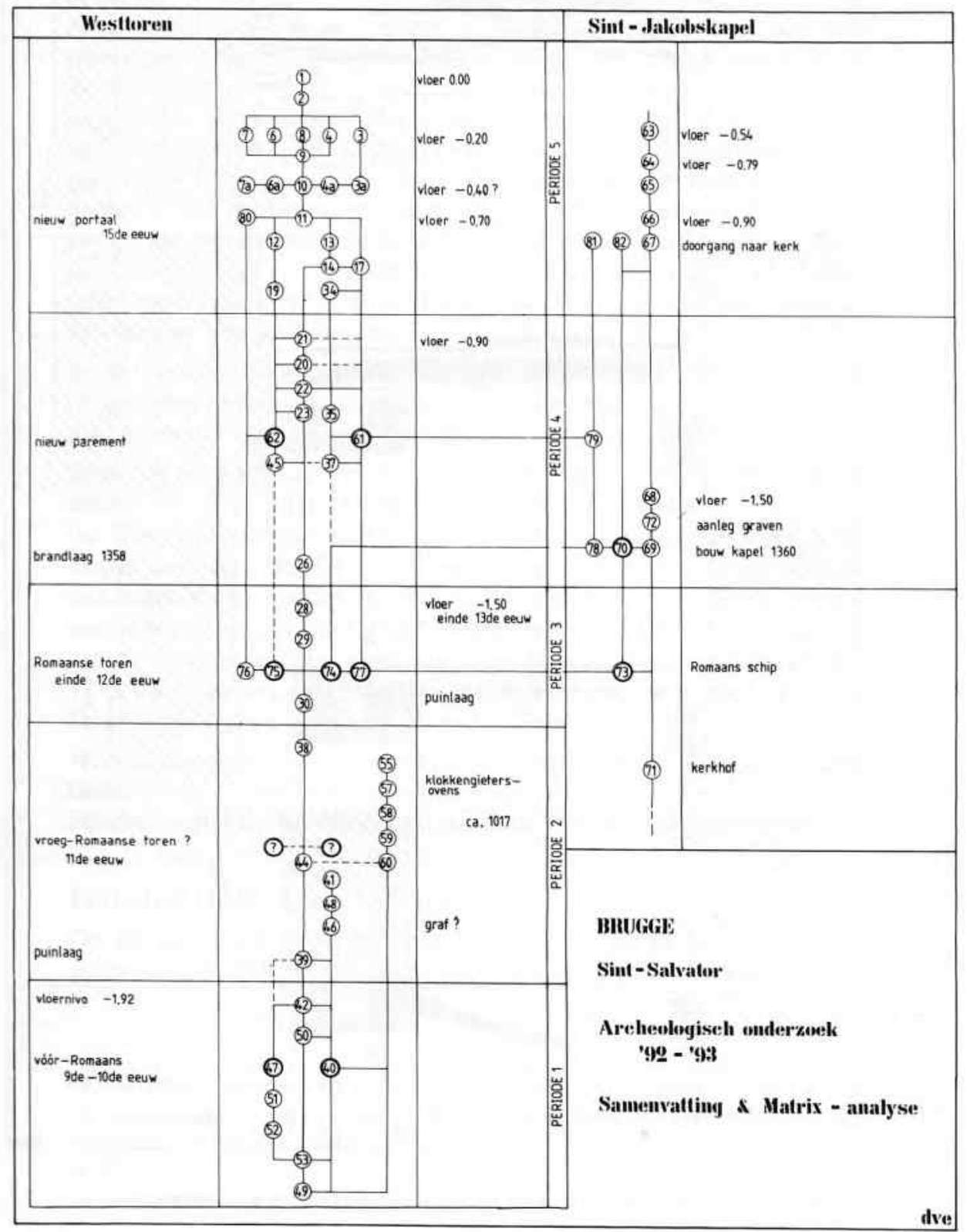


nog romaanse schip uitbrandden ${ }^{25}$. Dat de verwoestingen in de toren aanzienlijk waren, bewijst de $30 \mathrm{~cm}$ dikke brandlaag (nr. 26), hoofdzakelijk bestaande uit houtskool, die bovenop de hogervermelde baksteenvloer lag.

Kort na de brand, ca. 1360 (periode 4a), werd tegen de zuidkant van de toren de Sint-Jacobskapel gebouwd ${ }^{26}$. Deze in grondplan vierkante kapel (nr. 70) was enkel toegankelijk via een in de zuidwand van de toren uitgehakte deuropening (nr. 78), voorzien van een omlijsting ín Doornikse kalksteen.

Uit het onderzoek bleek dat de oostmuur van de kapel aangebouwd was tegen de veldstenen funderingen van de romaanse zijbeuk (die toen zelf waarschijnlijk reeds was afgebroken), en gefundeerd was in gemengde grond waarin enkele inhumaties, soms doorsneden door de nieuwe muur, werden aangetroffen (nr. 71). De Sint-Jacobskapel werd dus gebouwd op een deel van het romaanse kerkhof. $\mathrm{Na}$ de bouw van de kapel werd binnenin een 1,24 m dikke opvullingslaag aangebracht, waarin veel mortel en baksteenpuin (nr. 69). Waarschijnlijk reeds kort na de bouw van de kapel werden midden in de kapel drie bakstenen grafkelders gebouwd ${ }^{27}$; bovenop de graven en de opvulling van de bouwput (nr. 72) werd een nieuwe nivelleringslaag aangebracht (nr. 68). Zowel de eerste als deze tweede opvulling gaan samen met de bepleistering op de muren van de kapel, zodat het oudste vloerniveau op $-1,50 \mathrm{~m}$ kan vastgesteld worden.

Tegelijk met de bouw van het nieuwe, gotische schip werd ook de restauratie van de toren aangevat (periode $4 b$ ). Vooral de gelijkvloerse verdieping was blijkbaar erg aangetast (door de brandende balken van de ingestorte vloeren); tegen de veldstenen muren werd een gemiddeld $40 \mathrm{~cm}$ dik bakstenen parement aangebracht (nrs. 6162). De bouwput voor het nieuwe parement van de oostmuur (nr. 61) verstoorde de rand van een veldstenen muur uit periode 1 ; onderaan de bouwput kwam een veldstenen fundering waarop vanaf niveau $-2,30 \mathrm{~m}$ het bakstenen parement werd opgemetseld. Het nieuwe

25. Devliegher L., o.c., 1981, p. 18-19.

26. Devliegher L., o.c., 1981, p. 19 en p. 114-116.

27. Het beschilderde graf in de kapel werd beschreven door L. Devliegher, Middeleeuwse beschilderde graven in de Sint-Salvatorskathedraal te Brugge, in Monumenten en Landschappen, 14 (1995), afb. 1, p. 28-48 (inz. p. 47). 
parement tegen de westmuur begint op hetzelfde niveau, maar rust óp een veldstenen muur uit periode 1 : de funderingssleuf ( $\mathrm{nr} .45$ ) eindigt bovenop deze muur ; waarschijnlijk dachten de bouwers dat zij op een solide fundering waren gestoten.

Door het nieuwe parement in de toren moest de toegang naar de Sint-Jacboskapel aangepast worden ; er werd een nieuwe smallere doorgang gecreëerd, opnieuw met een omlijsting in Doornikse kalksteen.

De vernieuwde benedenverdieping van de toren werd afgewerkt met een gewelf, getuige de hoekzuilen die de aanzet vormden voor de ribben van het gewelf (dat bij een grote brand in 1839 verloren ging en vervangen werd door het huidige gewelf). In de fundering van de hoekzuilen werd herbruikmateriaal aangetroffen, zoals fragmenten van grafplaten, waarvan één gedateerd is in 1353. Zowel uit deze funderingen, als uit de stratigrafie blijkt dat het nieuwe vloerniveau gevoelig hoger kwam te liggen, namelijk op $-0,90 \mathrm{~m}$. Op dit niveau troffen we resten aan van een vloer in zandsteentegels, in kalkmortel gelegd op een lensje baksteengruis (nr. 21). Hieronder bevinden zich een puinlaag met baksteen en kalkmortel ( $\mathrm{nr}$. 23), een gemengde opvullingslaag (nr. 35), een opvulling met donkere aarde (nr. 22) en tenslotte een nivelleringslaag (nr. 20).

\section{Periode 5 (15de eeuw - 1992)}

In 1422 verkreeg het ambacht van de lakensnijders de Sint-Jacobskapel; waarschijnlijk in hun opdracht werd de kapel opnieuw geschilderd ${ }^{28}$. Hierbij hoorde ook het creëren van een nieuwe toegang tot de kapel: de oorspronkelijke deuropening vanuit de toren werd dichtgemetseld (nr. 81), en een nieuwe doorgang gehakt doorheen de oostmuur van de kapel en de westmuur van de zuidelijke zijbeuk (nr. 82). Tot deze aanpassing behoort ook een nieuw vloerniveau (op - $0,90 \mathrm{~m}$ ), aangeduid door een puin- en mortellaag (nr. 66) bovenop een opvullingslaag ( $\mathrm{nr}$. 67, aarde waarin enkele beenderen).

28. Devliegher L.. o.c., 1981, p. 38. 
In 1576 werd de kapel gerenoveerd ${ }^{29}$; het nieuwe vloerniveau (op $0,79 \mathrm{~m}$ ) bestaat uit een bakstenen vloer ( $\mathrm{nr}$. 64) die rust op een aarden opvullingslaag (nr. 65).

Een laatste vloerverhoging had mogelijk plaats omstreeks 1757 , toen de kapel als kerkmeesterskamer werd heringericht ${ }^{30}$; de nieuwe bakstenen vloer lag nu op hetzelfde niveau als de vloer in de kerk.

Ook in de toren vallen nog enkele verbouwingen en vloerverhogingen te melden. Bijzonder spijtig was het verdwijnen, in de 15 de eeuw, van het romaans portaal, dat werd vervangen door de huidige, banale ingang (nr. 80) in de westgevel. Bij deze verbouwing hoort, vanzelfsprekend, een nieuw vloerniveau ( $\mathrm{nr} .11$, op $-0,70 \mathrm{~m}$ ), aangelegd op enkele opvullings- en nivelleringslagen.

Het volgend vloerniveau (op $-0,40 \mathrm{~m}$ ?) ontstond naar aanleiding van het aanbrengen van twee houten tussenschotten die de doorgang naar de kerk versmalden. Getuige hiervan zijn vier in baksteen gemetselde funderingen (nrs. 7a, 6a, 4a en 3a). Nadien werd het vloerpeil nog tweemaal verhoogd, eerst tot niveau $-0,20 \mathrm{~m}$, waarbij voormelde funderingen iets werden verhoogd (nrs. 7, 6, 4 en 3), en tenslotte tot het huidige niveau.

\section{Periode 6 (1992- )}

Van de hier beschreven archeologische lagen blijft sinds de restauratie bitter weinig over : in de toren is alles verdwenen tot op niveau $-2,50 \mathrm{~m}$, en verdween door de nieuwe funderingen alle samenhang tussen de toren en de bewaard gebleven resten. Ook in de SintJacobskapel verdwenen nagenoeg alle archeologische lagen.

Vanzelfsprekend was een en ander onvermijdbaar door de omvangrijke ingrepen die noodzakelijk waren om de stabiliteit van de toren te garanderen ; toch is dit een goede illustratie van de omvang, rijkdom en belangrijkheid van het archeologisch bodemarchief dat bij dergelijke grote werken verloren gaat, en van de absolute noodzaak om dergelijke werken te doen samen - en/of voorafgaan met/van een archeologisch onderzoek.

29. In de steigers, jg. 1 (1994) nr. 1. p. 18.

30. Devliegher L., o.c., 1981. p. 114. 


\title{
BIJLAGE.
}

\section{Datering van een klokkengietersoven uit St.-Salvators}

\author{
Mark VAN Strydonck
}

Tijdens het onderzoek van twee klokkengietersovens in de toren van de St.Salvatorskathedraal te Brugge werd er materiaal gerecupereerd dat verband houdt met het ter plekke gieten van twee klokken. Op het eerste gezicht ging het om brokken houtskool, metaalslakken en brokstukken van de gietmantel. Vermeende stukken houtskool, afkomstig uit een afvallaag tussen de ovens, werden ter datering aangeboden. In het laboratorium werd duidelijk dat het niet om houtskool ging maar om een samengedrukte kleilaag waarin houtskoolpoeder verspreid aanwezig was.

\section{Behandeling}

Het materiaal werd verpoederd en gewassen met $\mathrm{HCl}$ om carbonaatneerslag (uit grondwater) te verwijderen. Gezien de compactheid van de laag en daar het staal afkomstig is uit een context zonder jongere vegetatie mogen we veronderstellen dat het houtskoolpoeder niet gecontamineerd is door jongere humuszuren.

Alhoewel er voldoende materiaal beschikbaar was voor een conventionele datering werd er wegens de natuur van het staal toch gekozen voor een AMS/datering. Tijdens de verbranding van het staal, met als doel de aanwezige koolstof om te zetten in $\mathrm{CO}_{2}$-gas, zullen polluerende stoffen uit de kleimatrix mee vergassen. Dit maakt een doorgedreven reiniging van het $\mathrm{CO}_{2}$-gas nodig. Daar deze reiniging veel gemakkelijker uit te voeren is op een klein staal en wegens de lage concentratie aan koolstof in het monster werd voor een AMS datering geopteerd. Het is van dit $\mathrm{CO}_{2}$-gas dat, na transformaties, de resterende radioactiviteit gemeten werd.

\section{Resultaat}

UtC- $3193^{\prime}: 1020 \pm 40$ BP.

Gekalibreerde ouderdom (Van Strydonck, 1987; Stuiver \& Pearson, 1993; Stuiver \& Reimer, 1993)

$68,3 \%(1 \sigma)$ bereik : $980-1040 \mathrm{cal}$ AD

$95,4 \%(2 \sigma)$ bereik : $900-1160 \mathrm{cal}$ AD

1. Staal bereid op het K.I.K. en gemeten in het Van de Graaff laboratorium, Universiteit Utrecht (Van Strydonck en Van der Borg, 1990). 


\section{Bespreking}

Het resultaat geeft een ouderdom voor het houtskoolpoeder gaande van de tiende tot de twaalfde eeuw met een maximum waarschijnlijkheid voor de periode tussen 980 en $1040 \mathrm{AD}$. Er moet rekening gehouden worden met de natuur van het materiaal bij de archeologische interpretatie van dit resultaat. Het houtskoolpoeder bestaat hoogstwaarschijnlijk uit een mengeling van houtskool afkomstig van verschillende stukken hout en bomen. Wij hebben geen informatie over de ouderdom van de stukken hout die verbrand werden. Gaat het enkel om bomen en twijgen waarvan de eigen leeftijd klein is vergeleken bij de standaardafwijking op de meting, dan zal dit geen effekt hebben op de ouderdom van het staal. Is het houtskoolpoeder afkomstig van oude bomen ( $>100$ jaar oud) dan zal een "oud-houteffekt" in mindere of meerdere mate de ouderdom van het staal beïnvloeden.

\section{Referenties}

Minze Stuiver and Gordon Pearson, 1993, High-precision bidecadal calibration of the radiocarbon time scale, AD 1950-500 BC-Radiocarbon, 35, 1-34.

Minze Stuiver and Paula J. Reimer, 1993, Extended ${ }^{14} \mathrm{C}$ data base and revised CALIB $3.0^{14} \mathrm{C}$ age calibration program - Radiocarbon, 35, p. 215-230.

Mark Van Strydonck, 1987, Kalibreren van ${ }^{14} \mathrm{C}$-dateringen - Archaeologia Belgica, 3, p. 281-288.

Mark Van Strydonck en Klaas van der Borg, 1991, A technical note concerning the construction of a preparation line for AMS-targets at the Royal Institute of Cultural Heritage - Bulletin van het koninklijk Instituut voor het Kunstpatrimonium, XXIII, p. 228-234. 